\title{
Fragmentos do teatro de Antonin Artaud e costuras de telas de H.B.
}

\author{
Luciana Abreu Jardim ${ }^{1}$
}

\begin{abstract}
The essay intends to reflect on chosen images of the painter Hieronymus Bosch in the light of possible aesthetic crossings with Antonin Artaud's theater of cruelty. For this, I look for some pictorial choices of Artaud that are manifested in his complete works, calling attention to the relationship he established between painting and writing. In the experience of writing about paintings, the theoretical basis chosen is supported by Julia Kristeva's Intimate Revolt (1997) and, in another perspective, in Capital Visions (1998) and Possessions (1998). In the course of writing, stimulated by the writing of the ghosts, according to the works mentioned above, I intend to bring to light phantom fragments, between the particular and the universal, of my heritage.
\end{abstract}

Keywords: image; intimate writing; painting; literature.

Resumo: $\mathrm{O}$ ensaio pretende refletir sobre imagens escolhidas do pintor Hieronymus Bosch à luz de possíveis cruzamentos estéticos com o teatro da crueldade, de Antonin Artaud. Para tanto, busco algumas escolhas pictóricas de Artaud que se manifestam em suas obras completas, chamando a atenção para a relação por ele estabelecida entre pintura e escrita. Na experiência de escrever sobre pinturas, a fundamentação teórica escolhida encontra respaldo na teoria acerca do íntimo, exposta por Julia Kristeva, em A revolta íntima (1997) e, sob outra perspectiva, em Visões capitais (1998) e Possessões (1998). No percurso de escrita, estimulada pela formulação dos fantasmas, conforme as obras supracitadas, pretendo pôr em evidência fragmentos fantasmais, entre o particular e o universal, da minha herança.

Palavras-chave: imagem; escrita do íntimo; pintura; literatura.

J'aimais mieux tuer le temps dans les galeries de la rue de Seine ou de la rue La Boétie: la peinture me sortait de moi-même. J'essayais d'en sortir.

Simone de Beauvoir

Considerações iniciais ${ }^{2}$

O conjunto de textos de Antonin Artaud que lança a original concepção do teatro deste artista singular recebe o título $O$ teatro e seu duplo. Publicado em 1938, período em que estava internado no asilo psiquiátrico de Quatre-Mares de Sotteville-lès-rouen, o autor

1 Pós-doutoranda em Letras FURG, Capes/PNPD.

2 Este artigo é resultado parcial da minha pesquisa de pós-doutorado em Letras UFRGS/Capes, realizada sob a supervisão da Profa. Dra. Maria da Glória Bordini, entre os anos de 2008 e 2010. 
sequer pode ter acesso à obra durante o momento de sua publicação ${ }^{3}$. Essa obra compõe-se de uma série de artigos e cartas. O material produzido durante os anos de 1931 a 1935 teve como pano de fundo o afastamento de Artaud, no ano de 1931, da proposta teatral do Teatro de Jarry, considerado naquele período uma experiência teatral revolucionária. Sem desistir do ímpeto revolucionário presente nesse teatro, Artaud busca um caminho próprio. Segundo Grossman (2006, p. 38), algumas experiências marcantes pontuam a trajetória dele: a descoberta dos dançarinos balineses numa exposição em Paris, em 1931; o fracasso da encenação da peça dos Cenci e a viagem ao México, em 1936. Desses acontecimentos contrastantes, surge a primeira versão do teatro da crueldade.

A definição de teatro, segundo a proposta artaudiana, parece uma tarefa que mobiliza os críticos de diferentes momentos de nossa história artística contemporânea e correntes distintas do pensamento.

$\mathrm{Na}$ intenção de apresentar a inovação de seu teatro, que pode ser lida como um retorno à linguagem não-verbal presente nas representações orientais, Artaud se interroga sobre a necessidade do diálogo no teatro ocidental. Para o autor, o teatro não se limita a cenas dialogadas, sendo também possível manifestar-se por meio de uma gestualidade que ele percebe nas coreografias balinesas, nos cenários e, de modo especial, na atividade dos pintores. $\mathrm{O}$ ponto que elegemos para seguir adiante na inspeção do teatro artaudiano diz respeito à ênfase que ele concede a expressões pictóricas. É notável a descrição que ele faz de "As filhas de Loth", de Lucas van den Leyden, em O teatro e seu duplo, chegando a sustentar a tese segundo a qual "essa pintura é o que o teatro deveria ser, se soubesse falar a linguagem que lhe pertence" (2006, p. 35). Depois de uma visita ao Louvre, essa tela o leva a proferir uma palestra intitulada "La Mise en scène et la Métaphysique", no anfiteatro Michelet da Sorbonne, sob a coordenação do Dr. Allendy, psiquiatra que transitava na área artística ${ }^{4}$. O texto participa do volume $O$ teatro e seu duplo e expõe uma longa descrição dessa tela até alcançar elementos da natureza como o fogo e o vento, que são por ele capturados com a mesma atenção e intensidade com que descreve os personagens que fabricam a narrativa incestuosa da cena bíblica. Artaud desloca a importância das cenas dialogadas para o que chama de "poesia do espaço", que "consiste em tudo o que ocupa a cena, em tudo aquilo que pode se manifestar e exprimir materialmente numa cena, e que se dirige antes de mais nada aos sentidos em vez de se dirigir em primeiro lugar ao espírito 5 ." (2006, p. 36-37). A pintura, na categoria das artes plásticas, seria, portanto, um dos elementos de expressão da cena. Estamos diante de uma proposta alternativa ao que usualmente circula na ordem das palavras, ou seja, da linguagem verbal. $\mathrm{O}$ autor sugere uma substituição do que designa de "poesia da linguagem" por uma "poesia no espaço".

\section{Da escrita do íntimo}

Como escrever sobre o teatro de Antonin Artaud, sob uma perspectiva que pretende se deslocar da linguagem verbal, sem cair numa proposta que é rechaçada por seu idealizador, qual seja, a da estagnação da poesia da linguagem?

3 Cf. Grossman, em ARTAUD, A. Un insurgé du corps. [s.1.]: Découvertes Gallimard, 2006, p. 37.

4 Cf. Mèredieu, 2006, p. 446.

5 "Fondé à Pigalle, par Oscar Méténier, en 1897, Le théâtre du Grand-guignol attira vite les foules avides de bizarreries, de sang, de lyrisme et de gouaille; les bourgeois et les intellectuels vinrent s'y encanailler. On est là souvent à mi-chemin du vaudeville et de la séance spirite. La scène théâtrale y est - au sens littéral du terme - cette table de dissection, ou l'on ouvre et découpe les corps. Préfiguration de cette opération chirurgicale que préconisera Artaud" (2006, p. 463-464). 
Comecemos pela exposição do íntimo. O contato com o íntimo, na teoria de Julia Kristeva, é tributário de uma experiência-revolta. Por revolta, não se trata de buscar o sentido mais imediato dessa palavra, que reenvia à sua acepção de mudança política, tendo, como a própria autora investiga em Sentido e contrassenso da revolta, em Voltaire e seu O século de Luís XIV, o caminho traçado para consolidá-la na direção de uma revolução que culminou nos contornos marcadamente políticos do termo no século 18 . O enfoque da experiência-revolta ambicionada por Kristeva não é a mudança política e, embora o seu desdobramento repercuta sobre os possíveis caminhos sociais contemporâneos, a autora traz à tona uma formação mais antiga da revolta, distanciada dessa conotação política. Como salienta, na medida em que volvere (do latim), por intermédio de influência italiana nos séculos XV e XVI e da francesa volute, aqui como termo da arquitetura, passando pelas formas volta e voltare, sugere "a ideia de um movimento circular e, por extensão, de um retorno temporal" (2000, p. 14), que se distancia, portanto, de uma herança política e ao mesmo tempo instaura uma busca. $\mathrm{O}$ íntimo seria um retorno ainda mais radical, uma volta que acompanha a origem latina da palavra, intimus, segundo Kristeva, em A revolta intima (1997, p. 69). Estamos diante do "mais interior" e, embora ligado ao inconsciente, nas palavras da autora, o íntimo "não deve se reduzir a ele", mas "ultrapassá-lo". Coube à Psicanálise, de acordo com o argumento de Kristeva, a retomada do íntimo a partir da ligação que Freud estabelece entre alma, corpo e a própria esfera do íntimo, levando, assim, a estabelecer o reconhecimento de uma "essência" do íntimo por meio de uma "continuidade heterogênea entre corpo-alma-espírito" (1997, p. 80). Nesse sentido contemporâneo do íntimo mediado pelo discurso psicanalítico, tal foro íntimo se define como "o mais profundo e o mais singular da experiência humana" (1997, p. 69). Tendo como herança a experiência de uma visão interior, que alude aos textos dos místicos, na leitura de Kristeva, o íntimo não se reduz à percepção ou ao pensamento, mas se transforma em imagem, ou, em outra formulação escolhida pela autora para estabelecer a ponte com a teoria psicanalítica, se transforma em imaginário. No acesso às imagens e, por conseguinte ao que chama de busca ou resgate do íntimo, a autora retorna aos fantasmas, formação conceitual freudiana, para realçar uma estrutura pré-subjetiva. Kristeva alicerça o conceito de experiência-revolta sobre a retomada de um tipo especial de elementos inconscientes que Freud chama de fantasmas originários. A teórica enfatiza que esses fantasmas originários "não constituem necessariamente uma sedimentação de experiências individuais, mas de esquemas hereditários" (1997, p. 105), citando Freud em Introdução à psicanálise (1915-1917) sobre o tema: "o fantasma 'cobre, com a ajuda da verdade pré-histórica, a lacuna da verdade individual ${ }^{6 ", "}$.

$\mathrm{O}$ acesso a esses fantasmas, para além da prática analítica, que não é o nosso objetivo nesse ensaio, pode ser percebido em atividades artísticas, sendo que a literatura e as artes, segundo a autora (1997, p. 106), constituem os lugares de acolhida dos fantasmas, lugares que a autora constata como sendo propícios para a "formulação de fantasmas". Note-se que a palavra "formulação", opção da autora, é diferente de uma resposta acabada e precisa para a inspeção do íntimo que ela nos propõe. Entre o capturar fantasmas, sejam eles conscientes ou arraigados em nossa trama mais profunda do inconsciente, eclode a experiência de contato com a vida íntima. Como mediadora dessa experiência, Kristeva reconhece na escrita um exercício capaz de dar vazão a um conteúdo amiúde sob

6 “(...) le fantasme 'comble, à l'aide de la vérité préhistorique, la lacune de la vérité individuelle”" (1997, p. 105). 
o domínio de uma cultura visual, eminentemente massificada e em choque com a vida do espírito, correlato arendtiano da experiência íntima. Kristeva observa no gênero do romance o que chama "terreno privilegiado" (1997, p. 10) para a comunicação e escrita de um conteúdo fantasmal de resgate da vida íntima. Ao lado dessa prática romanesca, acrescentamos a escrita sobre pinturas, que põe em evidência manifestações fantasmais do "vir à luz", "brilhar" "aparecer", "apresentar", "se apresentar", "se representar" (1997, p. 101), as quais são por ela desenvolvidas em Visions capitales e sobre a qual se faz um retorno ainda mais radical da experiência-revolta. Trata-se, portanto, de um deslocamento do imperativo visual reiteradamente criticado pela autora, uma busca pelo íntimo sem a recusa da raiz grega que acompanha o resgate etimológico do "aparecer". Buscaremos, assim, escrever fragmentos de uma experiência-revolta possível, por intermédio de alguns fantasmas que compõem o teatro da crueldade de Antonin Artaud, no cruzamento com telas escritas por ele e outras retratadas por Hieronymus Bosch, uma espécie de mosaico alternativo à saturação e mitificação de imagens da atualidade.

\section{Nota sobre a relação Artaud e as artes plásticas}

Alain Virmaux observa na produção de Artaud um fascínio pelo mundo da pintura que o levou a escrever crônicas sobre as exposições em Paris e a pensar num teatro com esse apelo imagético (2000, p. 158). Para Paule Thévenin (1993, p 135-36), o interesse de Artaud pela pintura e sua relação com o teatro é anterior à descoberta do quadro de Lucas van den Leyden e às visitas do autor ao Louvre. Desde pelo menos o ano de 1924, ele já havia percebido e estabelecido esse vínculo, de acordo com o texto "L'évolution du décor". Segundo Paule Thévenin (1993, p. 136), esse texto ${ }^{7}$ pode ser considerado um manifesto que marca o interesse do autor pelo universo da pintura.

Observa-se que a releitura do teatro da crueldade de Antonin Artaud sob a perspectiva das artes plásticas se desenvolve frequentemente através dos trabalhos pictóricos do próprio escritor, que deixou uma série de desenhos enquanto perambulava por asilos psiquiátricos. Os desenhos artaudianos, autorretratos agônicos de um artista em constante crise com as limitações linguísticas correntes, constituem importante material para pesquisadores em busca de referências interdisciplinares sobre uma vida-obra que nunca se dissociou de um interessante vínculo autobiográfico e até mesmo curativo. Em carta de 5 de fevereiro de 1945 ao Dr. Ferdière, o autor responsabiliza a série de internações e os tratamentos aos quais foi submetido por nove longos anos pelo seu estado deplorável, que é por ele descrito como parte de uma condição bestial, sendo a atividade do desenho, que fora estimulada na ocasião de sua passagem pelo asilo de Rodez sob os cuidados do Dr. Ferdière ${ }^{8}$, um recurso de "Retorno à Vida" (Nouveaux écrits de Rodez, 1977. p. 79).

7 “Que l'on jette les yeux sur la peinture. Il y a, à l'heure qu'il est, de jeunes peintres qui ont retrouvé le sens de la véritable peinture. Ils peignent des joueursd'échecs ou de cartes qui sont semblables à des dieux*" (ARTAUD apud THÉVENIN, 1993, p. 136. *OC II, 10).

8 Durante o período em Rodez, sob a supervisão de Ferdière, seguidor da arte terapia, Artaud produziu dois textos adaptados de Lewis Carroll: Variations à propos d'un teme et Le Chevalier Mate-Tapis, além de ter recriado o sétimo capítulo de Através do espelho, com o título L'Arve et l'Aume, que representou uma "tentativa antigramatical contra Lewis Carroll". Cf. ARTAUD, A. Un insurgé du corps. [s.1.]: Découvertes Gallimard, 2006, p. 66. 
Je suis très heureux que mes dessins vous aient plu, parce qu'il y avait plus de vingt ans que je n'avais pas dessiné et je m 'étais jamais essayé dans le dessin d'imagination et il y a à peine quinze jours je ne me croyais pas capable d'exprimer mes idées par ce moyen-là. Et c'est à instigation pressante de F. Delanglade qui est un véritable et un très profond ami que je m'y suis essayé (ARTAUD, 1977, p. 78).

No volume XIV de suas obras completas (p. 148), edição Gallimard, Artaud comenta que seus primeiros rabiscos foram feitos no ano de 1939, no asilo de Ville-Évrard, o que mostra que não estava tão afastado da atividade do desenho como anuncia na carta acima, endereçada ao psiquiatra. Paule Thévenin, que entrou em estreito contato com Artaud, além de ter feito a laboriosa transcrição de seus cadernos, afirma, de acordo com o depoimento dos amigos do dramaturgo, que ele escrevia incansavelmente: "Ele não ficava uma hora sem escrever ou desenhar" (1993, p. 161). Observe-se que o vínculo do autor com os autorretratos, mais importante do que situá-lo entre os expoentes artistas visuais populares e vanguardistas de sua época, ou do que flagrar os inícios de sua produção imagética na intenção de compará-los com os escritos desse autor, promove antes outra interpretação de sua obra, ampliando enfoques meramente psicológicos, os quais, sem saírem de cena, se somam ao estilo expressivo de traço do autor, manifestando-se em luta com uma autoimagem fragmentada ou em processo de uma face em dissolução. Diferentemente de uma abordagem que privilegia os desenhos do autor ${ }^{10}$, escolhemos algumas referências imagéticas que circulam geralmente dissociadas do idealizador do teatro da crueldade, e, no entanto, atuam sub-repticiamente na composição desse teatro. Algumas referências periféricas em textos dispersos de Artaud formarão o nosso caminho exploratório nesse ensaio.

Da provável observação de telas de Monticelli, por exemplo, derivam aspectos do conceito de beleza adotado por Artaud, segundo o texto "L'art et la grandeur", no qual ele reconhece que a beleza necessita de "grandeza" e de "alguma solenidade" para se tornar perceptível (OC II, 1980, p. 182). Todavia, essa observação não pode ser tomada sem que se retorne à própria ambição do artista pelo que denomina de invisibilidade, ou àqueles estados de sensações escorregadias almejadas pelo teatro da crueldade, no artigo "Teatro oriental e teatro ocidental", estados em que a comunicação se pretende para além da materialidade da própria língua:

Et il ne s'agit pas de savoir si le langage physique du théatre est capable d'arriver aux mêmes résolutions psychologiques que le langage des mots, s'il peut exprimer des sentiments et des passions aussi bien que les mots, mais s'il n'y a pas dans le domaine de la pensée et de l'intelligence des attitudes que les mots sont incapables de prendre et que les gestes et tout ce qui participe du langage dans l'espace atteignent avec plus de précision qu'eux ${ }^{l l}$ (ARTAUD, OC IV, 1978, p. 69).

9 "Eu estou muito feliz que meus desenhos o tenham agradado, porque havia mais de vinte anos que eu não desenhava e estava sempre envolvido no desenho da imaginação e há apenas quinze dias eu não acreditava ser capaz de expressar as minhas ideias por esse meio. E foi pela insistente instigação de F. Delanglade, que é um verdadeiro e muito profundo amigo, que eu tentei" (ARTAUD, 1977, p. 78, tradução nossa).

10 Jacques Derrida, entre outras obras sobre o mesmo tema, escreveu sobre os desenhos de Artaud em 2002, na obra Artaud, le Moma. Sobre os desenhos de Antonin Artaud, o trabalho de Virmaux (2000, p. 158) recupera algumas fontes importantes sobre o tema: G. Charbonnier (Ensaio sobre A.A.), Dr. J.L. Armand-Laroche (A.A e seu Duplo) e podemos encontrar os desenhos na revista L'Ephémère, n. 8 (1968).

11 "E não se trata de saber se a linguagem física do teatro é capaz de chegar às mesmas resoluções psicológicas que a linguagem das palavras, se consegue expressar sentimentos e paixões tão bem quanto as palavras, mas de saber se não existe no domínio do pensamento e da inteligência atitudes que as palavras sejam incapazes de tomar e que os gestos e tudo o que participa da linguagem no espaço atingem com mais precisão do que elas" (ARTAUD, 2006, p. 78. Trad. Teixeira Coelho). 
No texto que inicia com a alusão ao trabalho de Monticelli, Artaud observa na beleza algo que lhe é exterior, ou seja, para além da própria obra contemplada, chamando esse processo de uma "invisível presença” (OC II, p. 183). Pintores que conseguiram esse efeito encantatório são em seguida elencados pelo autor; entre eles estão Giotto, Cimabue, Cranach, Brueghel, Téniers, Watteau e Le Nain. Curiosamente, como veremos mais adiante, tais pintores, à exceção de Brueghel, não são os escolhidos por Artaud para exemplificar os efeitos de impacto físico de seu teatro sui generis ${ }^{12}$. Subjacente à invisibilidade referida por Artaud, se desenvolve um trabalho que passa pela técnica, pois ele chama a atenção para o uso das cores aliado ao "equilíbrio de planos" e até mesmo à "solidez das estruturas" como características formadoras do talento desses artistas. O conjunto harmônico desses elementos produz um efeito estético que justifica a invisibilidade da presença e ao mesmo tempo a compõe como algo cercado de parâmetros, ainda que vagos e também para além de seus fantasmas. Artaud diferencia essa sensação produzida pela contemplação de pinturas - cuja experiência de grandeza leva à noção de eternidade por ele referida, assemelhando-se, como sustenta, às passagens da vida de um homem - da mera experiência de fugacidade superficial que provavelmente ele nota em manifestações estéticas superficiais, as quais atribui apenas o sentimento de uma busca ilusória na medida em que se perdem no esquecimento ao longo dos tempos.

Ligada à invisibilidade da presença pretendida por Artaud, está uma descrição que ele faz ao Dr. Allendy, no ano de 1927. Na carta, o autor descreve estados afetivos que o teriam levado tanto a experiências de plenitude de uma existência incomum porque tocada por dons criativos quanto a momentos de estagnação, em que afirma dispor de "alguma coisa apodrecida", como se já estivesse em parte paradoxalmente morto no auge da própria vida. (E não seria o caso de suspender a intenção de paradoxo na leitura artaudiana para deixar vir à tona outra formação? Nota-se a eclosão de experiências de desencontro com o fluxo conceitual, o que para ele causa desencaixe). Por meio de uma série de imagens, ocorre esse processo, que também pode ser interpretado à luz da fragmentação do sujeito falante, movimento no qual o autor é invadido por atmosferas de outras pessoas ou de um exercício constante de maquinação de pensar/sentir cuja subjetividade ele rechaça, além de esquecer a possível copresença desses termos. Assim ganha forma apenas a ideia de que a expressão de breves sensações é mediada por palavras:

Ces imagens dont l'authenticité fait la valeur, elles n'ont plus de valeur, n'étant que des effigies, des reflets de pensées antérieurement ruminées, ou ruminées par d'autres, non actuellement, et personellement PENSÉES. Comprenez-moi. Ce n'est pas même pas une question de qualité d'images, de quantité de pensées. C'est une question de vivacité fulgurante, de vérité, de réalité. Il n'y a plus de vie. La vie n'accompagne, n'illumine pas ce que

12 Virmaux observa que a lista de Artaud exclui alguns "pintores que em outras épocas Artaud reconhecia como seus: Lucas Cranach (I, 185), Delacroix (meu pintor preferido - I, 186), Paul Klee (um pintor mental - I, 196 e Re. 272) e sobretudo Van Gogh. Ele é atraído pelas obras pictóricas que exprimem uma visão dramática no sentido mais amplo da palavra: as que tornam sensível um confronto de forças em meio a uma iluminação confusa, dividida e trágica. Um confronto de Artaud com o mundo da pintura obriga, além do mais, a não esquecer dois homens que foram seus amigos: André Masson (o maior pintor do mundo - I, 64 e Re. I, 78) e Balthus; Artaud o descobrira no ano precedente (1934), como pintor (II, 248) e como cenógrafo de teatro (II, 179 e 181). Foi com a companhia de Dullin - que ele, em 1922, pôde presenciar e admirar Picasso trabalhando (R.B. 71, p. 12)" (VIRMAUX, 2000, p. 159). 
je pense. Je dis LA VIE. Je ne dis pas une couleur de vie. Je dis la vie vraie, l'illumination essentiellement: l'être. Le brasillement initial où s'enflamme tout pensée, - ce noyau. Je sens mon noyau mort. Et je souffre (ARTAUD, OC I, 2, 1976, p. 145) ${ }^{13}$.

No desenrolar dessa carta, Artaud ambiciona nada menos do que escapar das categorias do espaço e do tempo (1976, p. 146), além de afirmar que nunca trabalha e que tudo lhe chega, conforme suas palavras, "por acaso". Sem aludir a um possível trabalho do inconsciente, que seria uma resposta psicanalítica para fundamentar o seu processo criativo, os textos do artista sugerem que ele alcança o núcleo das "coisas", mas se trata de um núcleo morto, acompanhando assim a afirmação dele segundo a qual dispõe de alguma coisa apodrecida, que está, portanto, tanto na contracorrente da própria história filosófica do pensamento ocidental no que se refere ao distanciamento da ingênua necessidade de imediatidade com a própria experiência, quanto no estranhamento obliquamente inserido nessa história do pensamento filosófico, através, por exemplo, da obscura observação nietzschiana de que há alguma coisa de morto no vivo, assim como se apresenta em $A$ gaia ciência, $\S 109$, Terceiro Livro: "O que está vivo é apenas uma variedade daquilo que está morto, e uma variedade bastante rara.” (NIETZCHE, 2007).

\section{O canto de Uccello}

As referências ao pintor renascentista Paolo Uccello podem ser retomadas à luz da obsessão artaudiana pela presença invisível, assim como ele explora no texto "Paul les oiseaux ou La place de l'amour suivi de une prose pour l'homme au crane en citron" (1924), pertencente ao período surrealista do dramaturgo. Nesse caso, as descrições sobre o sentimento de amor que Artaud vislumbra em trabalhos de Uccello constituem o resgate invisível pretendido pelo dramaturgo, que o levam também ao movimento de autoinspeção, pois, segundo ele, do contato com a obra deste pintor surgem perguntas tais como: "O que é o amor? O que é o Espírito? O que é o Si-mesmo?" (OC I, 2, 1976, p. 9). Para Artaud, Uccello deveria ser retomado pelos grupos vanguardistas de modo a contribuir para o movimento surrealista: "Ele é ATUAL, quero dizer atual para nós, homens de 1924, e ele é ele mesmo. Ele é Paolo Uccello, e ele é o sem mito, e ele se faz PAULO OS PÁSSAROS ${ }^{14 "}$ (OC I, 2, 1976, p. 9). No texto que retrata um encontro possível entre Paolo Uccello e Brunelleschi, Artaud se confunde com Uccello, que, segundo o dramaturgo, construiu um edifício de "espiritualidade ilusória". Artaud escreve: "Tentei a fusão com o mito de Paolo Uccello. Eu me acantono no mito. Eu sou verdadeiramente Paulo os Pássaros". (OC I, 2, 1976, p. 12). Essa proximidade de intenção fusional não apaga alguma autoria pretendida por Artaud, uma vez que ele observa no resgate da vida-obra de Uccello algo que lhe atravessa como uma música pintada em jogo sinestésico de visão e

13 "Essas imagens, das quais a autenticidade produz o valor, elas não têm mais valor; não passam de efígies, de reflexos de pensamentos anteriormente ruminados, ou ruminados por outros, não atualmente ou pessoalmente PENSADOS. Entenda-me. Não é uma questão de qualidade de imagens, de quantidade de pensamentos. Essa é uma questão de vivacidade fulgurante, de verdade, de realidade. Não há lá mais vida. A vida não acompanha, não ilumina o que eu penso. Eu falo A VIDA. Não falo em uma cor de vida. Falo da vida verdadeira, a iluminação essencialmente: o ser. O braseiro inicial onde se inflama todo o pensamento, - esse núcleo. Sinto meu núcleo morto. E sofro" (ARTAUD, OC I, 2, 1976, p. 145).

14 "Il est ACTUEL, je veux dire actuel à nous, hommes de 1924, et il est lui-même. Il est Paolo Uccello, et il est son muthe, et il se fait PAUL LES OISEAUX" (OC I, 2, 1976, p. 12). 
audição, de aproximação fonética com um outro, que é trabalho de tradução e por isso de reconhecimento de outra língua e deslocamento e retorno modificado para a intimidade de seu próprio idioma (Paollo Uccello — Paul les Oiseaux), tal como sugere a expressão "me trabalha" ("me travaille"). Percebe-se também nessa imagem um atravessar que desemboca em voo semelhante àquele de Stravinsky em Firebird. E no entanto ele não se dissolve na experiência: "[...] eu sou eu mesmo. Eu não me perco da minha densidade. Eu e o Espírito, nós nos medimos cara a cara" (OC I, 2, 1976, p. 14). Na sequência dessa dissociação, o arrebatamento da experiência, possivelmente desencadeado pelo impacto decorrente das imagens inerentes à vida do pintor, somada à vida do autor do teatro da crueldade, parece contradizer a proteção do si mesmo, fazendo vir à tona um interessante conceito de vida para Artaud, no qual a própria vida do dramaturgo se desagrega, entrando em leve suspensão, para dar existência à obra de um outro ${ }^{15}$ (OC I, 2, 1976).

Em carta datada de 13 de abril de 1924, a Edmond Jaloux, Artaud (OC I, 2, 1976, p 108-109) comenta ter destruído Paolo Uccello há muito tempo. Todavia, o que se observa é a confissão do processo de sua própria perda dramática da linguagem, sendo por ele interpretada como uma experiência "cósmica" - processo que se manifesta neste caso específico por alusão indireta a imagens com as quais ele teria entrado em contato profundo para narrar a vida-obra de um pintor notável ${ }^{16}$.

É para um amigo invisível, interlocutor íntimo e imaginário, que ele escreve "Uccello, o pêlo", um texto publicado inicialmente em "La révolution surréaliste", em 1926, em estilo que flerta com surrealismo, no qual a imagem pássaro revela um deslocamento da ênfase da visão para uma espécie de escuta que não alcança a estridência de um grito animal, tampouco atinge a mudez que enuncia, mas antes o que produz é da ordem que prepara o caminho para os monstros em postura de homens-pássaros ou pássaros-monstros-homens do Jardim das delícias, de Hieronymus Bosch, aquelas figuras híbridas, cuja perda da forma apenas humana causa um estranhamento mais explícito do que esse estado intermediário percebido por Artaud, condição que, para além da filosofia aristotélica, e antes das metamorfoses kafkianas de personagens com sorrisos descarnados e exposição de assombrosas sensações patéticas, delineia um estado intermediário entre um canto animal, que não é somente um grito, mas se confunde antes, na recepção contemporânea de Artaud, com uma forma híbrida de questionamento das hierarquias entre homem e animal $^{17}$ (OC I, 1, 1976).

15 "Mas Paollo Uccello me chama e seu problema inconsistente. Tive a necessidade de dissolvê-los em mim, essa é a vida, essa é a vida. Toda a vida a cada instante. Tudo que rola no Espírito, todos os planos, todas as qualidades, todas as correntes. O pior, e o absurdo, o impoder, o esvaecimento" (ARTAUD, OC I, 2, 1976, p. 14).

16 "Desde muito tempo estou desabituado de pensar, de encontrar uma relação qualquer entre o nível de cada um dos meus pensamentos e meu nível geral do espírito. Por um fenômeno mórbido, mas que não seria oportuno agora descrever, as palavras frequentemente me faltam onde se solidificaria o meu pensamento, as expressões ou locuções usuais, a densidade interior das frases ou mesmo a solidez dos pensamentos sem frases, o ponto de partida do pensamento. Todo o meu espírito não é senão ausências, rupturas, esvaecimento. Falta-me a inconsciência, o esquecimento, a fusão do eu com o meu pensamento, mesmo se a densidade interior existe. Eu não sinto mais por assim dizer a necessidade do meu pensamento. Daí essas expressões larvárias, essas palavras frequentemente arriscadas." (ARTAUD, OC I, 2, 1976, P. 108-109).

17 "Mas abençoo também, Uccello, pequeno garoto, pequeno pássaro, pequena luz dilacerada, eu abençoo teu silêncio tão bem plantado. À exceção destas linhas que fazes brotar da cabeça como uma folhagem de mensagens, não resta de ti senão o silêncio e o segredo de tua túnica fechada. Dois ou três signos no ar, qual é o homem que pretende viver mais que estes três signos, e ao qual, ao longo das horas que o cobrem, se pensaria pedir mais que o silêncio que os precede ou que os segue [...]" (ARTAUD, 2004, p. 192, tradução de J. Guinsburg). 
Observe-se que a luminosidade descrita por Artaud participa da "invisível presença" que ele almeja, estando, portanto, na contracorrente do legado de visibilidade aristotélica, que está desenvolvida no primeiro livro da Metafísica, na qual o saber é associado à primazia da visão sobre os demais sentidos, demarcando assim os contornos estéticos e os imperativos de nossa herança eminentemente visual. A invisibilidade da presença nas telas de Uccello se acentua quando nos deslocamos para algumas imagens de Paul Klee, outra referência pictórica de Artaud, que acompanha esse legado visual sem, no entanto, estacionar numa mera descrição de um primeiro olhar sobre a cortante ingenuidade de figuras planificadas - flagrante já complexo em telas de Klee. No texto intitulado "Un peintre mental", Artaud defende que o trabalho de Paul Klee apresenta "[...] organização de visões, de formas, e também de fixação, com a conclusão decorrente daí, e também uma organização de imagens ${ }^{18}$ " (OC I, 1, 1984, p. 140), que não se limita à apreensão descritiva do objeto pintado, pois na continuação ele sustenta que se trata de uma "[...] pesquisa do sentido subjacente de certas imagens, clarificações de visões do espírito ${ }^{19}$ " (OC I, 1, 1984, p. 140). Percebe-se que a subjacência evidenciada pelo escritor desenha-se como outro nome possível da "invisível presença". Tal exercício de captura de efemeridade em tela pintada foi retomado recentemente por Julia Kristeva, em Visions capitales. Neste ensaio, a teórica da literatura retorna a algumas telas cujo tema das degolações e decapitações retrata uma interessante repetição de corte que compreende tanto as cabeças soltas, retratadas por Grünewald (Tête grimaçante), Picasso (Tetê de femme criant), quanto aquelas construídas por Andy Warhol (Marilyn Monroe) e Arnulf Rainer (Tête de vieillard). Artaud não escapa desse conjunto, e na descrição do autorretrato escolhido por Kristeva (1998) nota-se a mesma intenção de invisibilidade da presença que o próprio autor observara na qualidade de contemplador de quadros ${ }^{20}$.

O transe do corpo inteiro não é uma das intenções do teatro da crueldade? Uma escrita que não é suficiente para fazer esse trabalho se amplia, ou se desloca para o suporte do desenho - este é o argumento que se desenvolve na passagem supracitada. Desenho e escrita na produção artaudiana se complementam em projeto que é o desafiar a própria relação com os diferentes suportes, entre eles a voz, a escrita fonética, a delicadeza cruelmente trabalhada do sopro já referido por Derrida ${ }^{21}$, ou, de modo amplo, o traço, na condição do escritor de contemplador ou de desenhista. Desenho e escrita desencontram-se segundo o argumento de Kristeva; e o transe do corpo inteiro, que no teatro da crueldade aparece como experiência de "suspensão" (1998, p. 23-24), encontra em tela de Hieronymus

18 "Organisation de visions, de formes, et aussi fixation, stabilisation de pensées, inductions et déductions d'images, avec la conclusion qui en découle, et aussi organisation d'images" (ARTAUD, OC I, 1, 1984, p. 140).

19 "recherche du sens sous-jacent de certaines images, clarifications de visions de l'esprit" (ARTAUD, OC I, 1 , 1984, p. 140).

20 "O rosto de Artaud brilha de malícia, distante abaixo da loucura de suas mulheres, embaixo, através da boa mulher nele, entre a esquerda e a direita assimétricas desse rosto de esquizo que ele zomba muito ser, na condição de uma força, de um suspiro, uma precisão cortando papel, dispondo sombra e luz, captando as semelhanças, torcendo as aparências. 'Fiz o rosto de um velho império dos tempos bárbaros', diz o escritor a Paule Thévenin, para descrever o retrato que ele fez dela. [...] A escrita sozinha não bastará para forçar o vazio desse tempo bárbaro, será preciso o transe do corpo inteiro" (KRISTEVA, 1998, p. 122).

21 Conforme o ensaio "A palavra soprada" (DERRIDA, 2002, p. 115; 1967, p. 262). 
Bosch uma versão anterior às faces suspensas referidas por Kristeva, uma versão que é também de uma brutalidade que foge, por um triz, à construção da invisível presença descrita por Artaud, na medida em que esta antecede o momento em que cega o contemplador na expectativa de um além, sendo este brusca e brevemente encurtado em gesto que é semelhante ao de escansão do tempo. Nesse caso se trata de reconhecer o paradoxo, construído pela própria brutalidade de um corte cuja hiperexposição desafia o apelo espiritual por detrás de uma pretensa invisibilidade do objeto hiperiluminado. Por um triz acontece um contato bruto, e sobre esta experiência temos apenas fragmentos deixados por artistas em experiências de sensações-limítrofes. Na tela de Bosch, por exemplo, "A extração da pedra da loucura", antes de alcançarmos os olhos aliviados ou uma boca que se esparrama sob o efeito de um gozo proporcionado pela dor de um instrumento cortante, o que se sobressai é uma atmosfera pesada, saturada de visibilidade porque em contato com o drama que reúne imagens cruas de pele corada do homem imóvel, sentado na cadeira, e fios de sangue a alcançar o ouvido, que logo deslocam a atenção para o cordão vermelho envolvendo a veste do homem submetido à pseudocirurgia. $\mathrm{O}$ movimento de sutura da amarração da túnica branca a ser atravessada por uma linha que é continuação do corte explícito, metáfora da intenção de um teatro de "corpo inteiro", simboliza o que Artaud chama de sangue de imagens, sendo também um retorno à etimologia da crueldade. Segundo Artaud, no texto "Acabar com as obras-primas", a ação de crueldade participa de uma experiência de arrebatamento sangrento: "Uma ação violenta e densa é uma similitude do lirismo: invoca imagens sobrenaturais, um sangue de imagens, e um jorro sangrento de imagens tanto na cabeça do poeta quanto na do espectador ${ }^{22}$ " (2006, p. 92). O efeito de mal-estar da tela de Bosch faz-se também através da brutalidade da ambição desmedida de tocar com desenhos a própria condição da loucura, uma exposição que é atenuada pelo contexto medieval e o tom de zombaria que ele conferia aos retratados. A moldura que envolve a tela de Bosch traz uma inscrição, conforme elucida Walter Bosing (2006, p. 28), na qual se lê: "Mestre, tira-me depressa esta pedra. O meu nome é Lubbert Das". Segundo Bosing (2006, p. 28), a "extração" da pedra, que era ficcional, simbolizava a existência de uma estupidez a ser revelada pelo campo literário e ao mesmo tempo combatida, sendo que o nome Lubbert, na literatura flamenga, era associado a "pessoas extremamente estúpidas". E sobre essa loucura ainda pouco investigada na época de Bosch, a expressão "het scheren van de gek", cuja tradução inglesa é "shaving the fool" (barbeando o idiota), denota um sentimento de zombaria diante da loucura, de acordo com a investigação linguística de Hans van Gangelen e Sebastiaan Ostkamp ${ }^{23}$, reação que pode ser interpretada como a tentativa de descrever uma espécie de voo intuído- presença invisível de oiseau -, que se repete em suspensão delicada numa interessante tela recuperada por Kristeva para ilustrar uma série de cabeças cortadas, mas já distantes da brutalidade seguida de encobrimento misterioso de suspensão do quadro de Bosch.

O fecho com Artaud - ou se pode pensar numa ponte entre a tela boschiana, as escolhas pictóricas de Kristeva que o incluem como um zombador da própria loucura - acon-

22 "Une action violente et ramassée est une similitude de lyrisme: elle appelle des images surnaturelles, un sang d'images, et un jet sanglant d'images aussi bien dans la tête du poète que dans celle du spectateur." (ARTAUD, OC IV, 1978, p. 79-80).

23 Cf. "Parallels between Hieronymus Bosch's imagery and decorated material culture from the period between circa 1450 and 1525". (GANGELEN; OSTKAMP, 2001, p. 158). 
tece por meio da explicação de Kristeva, que, em visita ao Louvre, flagrou o que para o escritor-desenhista-dramaturgo se esboçava como um voo de presença invisível ${ }^{24}$

Esse deslocamento do imperativo visual para um jogo sinestésico de cores musicadas explode no despertar de sensações de ternura, que são desencadeadas ironicamente através do índice visual, no formato dos olhos fixos e das pupilas escuras, distanciados, portanto, do tremor vacilante que envolve o conjunto da tela, promovendo sensações adocicadas, as quais remontam a traços de afetividade características da modalidade linguística do semiótico ${ }^{25}$. No contraste com a fixidez do formato estático dos olhos, sobressai-se um movimento em tons de branco, como polvilhar açúcares refinados sobre a tela para apagar os contornos, produzindo sensação semelhante ao efeito morno e próximo do sabor açucarado do leite materno. A sensação é de "máscara sonora", na síntese de Kristeva, que é tributária da presença invisível sob a imagem de um grito de pássaro, segundo a nossa interpretação dos escritos artaudianos. É também a condição que acompanha a tese de Kristeva, exposta curiosamente em romance policial e retomada em Visions capitales, qual seja, a de que no horror não se vê, no horror se escuta, talvez. Em referência ao retrato da decapitação de São João, obra de Caravaggio, no romance policial Possessões, notam-se os deslocamentos da visão para escuta ${ }^{26}$.

Essa metáfora da degolação, no tom interrogativo e perturbador do ensaio de Kristeva, pode ser vista, de acordo com a sugestão da autora, como "emblema da divisão social", mas também serve de "confissão brutal de nossas fraturas internas, dessa instabilidade íntima que provoca os movimentos e também as crises" (1998, p. 114). Escolhemos sobretudo o segundo movimento, aquele que privilegia a esfera íntima dos contornos invisíveis, das sensações frágeis e encobertas que se apagam frequentemente em prol de uma busca por historicidade já demarcada, que muitas vezes se distancia de caminhos incertos e errantes, ou do impacto dos fantasmas originários, os quais constituem uma possível abordagem poética, de um passado cujos fantasmas se fragmentam no esquecimento de um retorno sempre diferido. O movimento em questão é de revolta poética, experiência imprevisível, portanto. Pode-se reconhecer nesse gesto de revolta, que é de retorno ao íntimo, mas também de um interior que participa do mundo - se levarmos em conta a possibilidade de entrar em contato com os fantasmas arcaicos -, novas experiências para além da rede fantasmática cristalizada por determinados grupos centralizadores dos contornos sinuosos do gosto e de suas possíveis interpretações.

24 “A Jovem idiota de Paul Klee é uma máscara sonora: as cores ressoam - nariz vermelho, olhos azuis, marrom ao redor, as hachuras coloridas lançam um véu sobre ele pra atenuar o grito de pássaro. Homem ou criança, a ingenuidade é idiota com seus olhos redondos, mas não é com tanta frequência que o mestre do Bauhaus se permite uma metáfora tão pura, tão terna, tão pouco geométrica. Uma inquietante estrangeiridade nos reconcilia, diante da cabeça flutuante dessa coruja perdida, com a nossa congenitalidade debilitada. Seria preciso acrescentá-la aos índices maiores do l'Unheimlich que Freud diagnostica no pânico sagrado que provoca a epilepsia, no medo de ser enterrado vivo, no gosto de evocar o espírito dos mortos, na angústia de se perder num bairro de prostituídos" (KRISTEVA, 1998, p. 114-115).

25 Sobre a modalidade linguística do semiótico, consultamos La révolution du langage poétique, 1974, p. 17-100.

26 'Une décollation, ce n'est pas pour la vue, voyons, c'est pour l'ouïe! D'ailleurs, toute peinture devrait être etendue. Mais comment? La décollation signe le terminus du visible. C'est la fin du spectacle, m'sieurs dames, circulez! Y a plus rien à voir! Ouvrez plutôt vos oreilles, si vous ne les avez point trop sensibles. Au fin fond de l'horreur, ça ne se voit pas: ça s'entend, peut-être" (KRISTEVA, 1996, p. 16). 


\section{Abalo da geometria de André Masson}

A escrita de Artaud a respeito de telas de André Masson produz relevantes apontamentos que se aproximam da nossa proposta de uma escrita do íntimo através do denso universo pictural. Adelaide Russo (1995, p. 262), em "Art et oscillation: l'oeil d'un 'certain philosophe", observa que, apesar do viés fenomenológico assaz próximo dessa corrente filosófica, não se pode localizar um uso sistemático de uma teoria em seus textos sobre pintura ${ }^{27}$. Ainda mais elucidativo sobre a intenção artaudiana de escrever sobre pintura é o ensaio de Monique Borie: "Pays de peinture e musique des sources". Segundo Borie, o autor transita no cruzamento de geografias que ela designa como cósmica, telúrica e interior ${ }^{28}$.

Nas telas de Masson, segundo Borie, Artaud busca estranhas paisagens, essas que the permitem o acesso a uma geografia interior, que não deixa de ser algo material, já que nesse espaço peculiar corpo e espírito se encontram, se reúnem em paisagem que evoca a natureza. Nesse espaço, há uma série de metáforas do sangue, do sofrimento e do fósforo (1989, p. 78), o que nos remete, é claro, ao teatro da crueldade. Borie busca, em "Fragments d'un Journal d'Enfer" (OC, I, I, p. 116), características desse espaço: imprevisível e fixo, formado por um tempo em constante movimento, interferências e trajetos. Borie reconhece o caráter paradoxal da paisagem interior artaudiana, isto é, o de reunir fixidez, uma forma ao que chama de "germinação" dessa paisagem. A pintura, nessa medida, viabiliza a materialização de uma visão interior. Borie associa essa visão interior à expressão "país de pintura", criada por Artaud para definir experiências de déjà vu pelas quais passou na viagem ao México $^{29}$. Essa aparição dos reis magos pontua o interesse do autor pelo passado de nossa tradição, seu lado mágico, místico, no qual ganha espaço o interesse pelo mistério da origem da vida, a gênese presente na natividade, que depois o levará a buscar relações entre pintores ocidentais, entre eles Bosch, e as cosmogonias pagãs.

O mistério da vida se apresenta muito bem problematizado no "Texto surrealista", que foi escrito, conforme a nota que o acompanha, sob a inspiração de telas de André Masson, com quem Artaud entrou em contato em Paris na década de 20, no qual Artaud menciona um mundo físico que "ainda está lá" (OC I, 2, 1976, p. 18) quando contemplamos o trabalho deste pintor. E nos perguntamos em que sentido se trata de um mundo físico para Artaud. Em seguida, ele acrescenta uma observação que altera essa experiência de presença física ou apenas a desenvolve para justificar o que outrora denominou de invisibilidade da presença, de modo a não esgotá-la numa simples questão de conferir privilégio ao olhar nas pinturas de Masson: "Mais quelque chose s'est produit tout à coup" (OC I, 2, 1976, p. 18).

De um conjunto de telas surrealistas que são as obras de André Masson, há um detalhe interessante de forças e universos peculiares que nos levam a associá-las a uma longínqua

27 Segundo Russo, "Il tâte l'objet en l'affrontant, sans vraiment savoir ce qu'il en pense, sans articuler des critères esthétiques préalables avant de s'engager dans le processos qui aboutit à la transformation de la vue en paroles" (1995, p. 262).

28 Cf. Borie, "C'est par rapport à cette double géographie, celle du monde et celle de l'homme, à ces marques des sources inscrites à la fois dans la géologie ou dans la géographie des spaces culturels, et dans la géographie interne de l'homme (celle du corps et celle de l'inconscient, des zones profondes du psychisme) que la peinture intervient chez Artaud" (1989, p. 74).

29 "C'étaient des réminiscences d'histoire qui venaient à moi, rocher par rocher, herbe par herbe, horizon par horizon. Je n'ai pas inventé l'apparition des Rois-Mages: ele m'a été minutieusement imposée par un pays construit comme des pays de peinture" (ARTAUD apud BORIE, OC, IX, p. 122). 
herança boschiana. Em Le labyrinthe, de 1938, a imagem mítica do minotauro, corpo de homem, cabeça de touro, ganha forma entre serpente, rochas e tons acinzentados, de um cinza cuja brutalidade esculpida por um passado de edificações marca, entretanto, o distanciamento do universo de apelo maravilhoso presente em telas de Bosch. Algo de monstruosidade talhada pelo pintor através de uma ossatura esbranquiçada, saída tanto do homem-touro quanto do pano de fundo, confere densidade que se distancia, por exemplo, de um desenho boschiano como $O$ homem-árvore. Percebe-se que algumas das sensações despertadas em Artaud pelos quadros de Masson refletem um abalo vítreo, de um envidraçado que destoa da descrição de evidência sangrenta, pois ele constrói uma aquarela para se aproximar também da frieza capturada por Masson. O vermelho em contato com água também produz o efeito de dissolução da geometria cubista de muitas telas de Masson, e por um momento Artaud o aproxima da vibração trêmula do amarelo, que reenvia, obviamente, a Van Gogh, por meio da musicalidade que reconhece neste pintor "un formidable musicien": "Eu vejo, no momento em que escrevo essas linhas, o rosto vermelho sangrento do pintor vir a mim, num muro de girassóis estripados, num formidável incêndio de fagulhas de jacinto opaco e de pastagem lapis-lazuli ${ }^{30 "}$ (OC XIII, 1974, p. 46-47). A máscara sonora de invisível presença envolve pois obliquamente o conjunto do trabalho pictórico de Masson, e, antes de cairmos num navio que é dos excluídos, voltamos ao horror deslocado da visão para a escuta e o ponto de apoio emerge do contato fantasmático com a minha própria experiência-revolta, que me atravessa por um texto de Michel Leiris, de 1968, cortado por telas de Masson e possivelmente pelo lado de vermelho solar antevisto por Artaud - elementos de uma violência a abalar a geometria: “[...] é lícito descobrir na tourada uma figura da união de contrários nitidamente distinta de uma simples associação de contrastes." (LEIRIS, 2001, p. 30).

A arte da tauromaquia mobiliza uma geometria especular que é manifesta nas telas de Masson, o touro e homem, o homem-animal e o contemplador do quadro, numa leitura que se permite reconhecer no espetáculo sempre de resultado brutal que é o das touradas uma capa de coreografias tensas e emoções limítrofes. O fascinante da interpretação de Leiris é capturar a "torção constante dessa geometria", uma experiência que desequilibra a expectativa da força do animal na medida em que o desfecho através da morte do touro se desencadeia por um gesto que é sobretudo de desvio, de fuga mais do que de valentia, na nossa interpretação. A experiência produz uma sequência de deslocamentos vibráteis entre touro e homem, sendo o touro já corpo de homem, e o toureiro um tanto metamorfoseado em energia de fúria a produzir um golpe de espada, de força para além de uma estrutura muscular meramente "humana", tornando-se, simultaneamente, vítima e algoz de uma situação que ultrapassa tanto os próprios envolvidos diretamente na cena quanto os espectadores. A lentidão do desequilíbrio, na cena em que os papéis estão sujeitos à surpresa de um desenrolar sempre tenso, é o que anima essa estética pautada por uma passionalidade que excede a geometria de Le labyrinthe, dissolvendo a aparência glacial de tons cujo efeito é o abrandamento de sensações de arrebatamento. Impetuosidade. Emoción é a expressão de Leiris; chacoalhar de um monde vitré aparece no texto de Ar-

30 "Je vois, à l'heure où j'écris ces lignes, le visage rouge sanglant du peintre venir à moi, dans une muraille de tournesols éventrés, dans un formidable embrasement d'escarbilles d'hyacinthe opaque et d'herbages de lapis-lazuli” (ARTAUD, OC XIII, 1974, p. 46-47). 
taud sobre as telas de Masson, entrecruzamento que ultrapassa o labirinto de fantasmas espanhóis, que são, é preciso realçar, da minha herança fantasmal ${ }^{31}$.

Embora Leiris tenha escrito sobre aspectos de uma experiência-limite que toca em zonas híbridas de contornos e deslocamentos que pretendem, numa fuga de aprofundamento e lentidão, diferir infinitamente o momento de gozo final, essa metáfora pungente da nossa loucura diante da sempre presente condição de mortalidade traz à tona um transporte aquático, um retorno ao gélido de branco-acinzentado do Le labyrinthe, de deslocamento do mítico para o bíblico, e que Hieronymus Bosch antecipa em sua nau dos insensatos. A água retratada pelo pintor medieval conduz à mediação entre os que foram possivelmente salvos, ou escolhidos, provavelmente pelos religiosos (que ocupam o centro confortável de uma espécie de mesa), e os excluídos, marcando interessante divisão entre o interior e o exterior da precária embarcação. Um dos retratados se apresenta em perfil suplicante e o outro, cujos braços delgados aludem à fragilidade da estrutura das formas monstruosas boschianas que seguem formas humanas ${ }^{32}$, despe-se de qualquer intenção de revolta que venha a perturbar a cantoria dos escolhidos. Chama a atenção aquele cuja expressão do rosto é de reverência perplexa diante de uma possível escolha; ele está deitado de lado e vira apenas o rosto para ser atendido enquanto segura um cantil. $\mathrm{O}$ gesto de encolhimento do corpo e a expressão do rosto entre gratidão hesitante e petrificação de constrangimento não encobre o apego ao que foi deixado, sendo que esse exterior, no movimento da mão agarrada à alça do cantil, indicia apego relacionado a estruturas eminentemente materiais ${ }^{33}$.

Percebe-se que o canto da freira, acompanhado de um banjo, da voz do monge e da indiferença do bobo de costas para a cena, atenua a atmosfera de zombaria que é flagrante no exemplo do painel Cruz às costas, no detalhe dos dentes estragados dos homens que acompanham o martírio de Cristo $^{34}$. Curiosamente, em $A$ nau dos insensatos, o pintor esconde o efeito dos dentes, o que não apaga a manifestação de zombaria do conjunto: os escolhidos, à exceção dos religiosos, são marginais. Para romper com a composição, que poderia desembocar em episódio próximo do risível, o pintor deixa margem para surpreendermos, na direção do olhar da freira, uma busca inalcançável. Qual seria o objeto de contemplação dela? O olhar enigmático da freira carrega o efeito de presença invisível artaudiana, alargando-se para a sugestão de Kristeva presente em Visions capitales e Pos-

31 "No que concerne ao próprio mecanismo do passe, constata-se que o que lhe dá sabor é aquele descompasso mínimo graças ao qual a tangência completa - que seria necessariamente catastrófica - é evitada: tudo concorre para dar a impressão dessa tangência, mas tudo permanece, no final das contas, ligeiramente aquém. Um aquém cuja grandeza infinitesimal se aprecia na medida da lentidão com que se move o homem, como se tencionasse - afora a necessidade do ritmo - instilar uma a uma, no coração do espectador, as aflições engendradas pela visão de um acidente filmado em câmara lenta ou de um navio que oscila e joga com lerdeza nauseante.” (LEIRIS, 2001, p. 34, grifos nossos).

32 Nas fontes formadoras do maravilhoso medieval, Jacques Le Goff (1989, p. 31) reconhece tanto o maravilhoso bíblico, que está retratado nos livros do Gênesis e do Apocalipse, quanto o maravilhoso antigo, através de personagens mitológicas.

33 Iahweh disse a Noé: "Entra na arca, tu e toda a tua família, porque és o único justo que vejo diante de mim no meio desta geração. De todos os animais puros, tomarás sete pares, o macho e a fêmea; dos animais que não são puros, tomarás um casal, o macho e sua fêmea (e também as aves do céu, sete pares, o macho e sua fêmea), para perpetuarem a raça sobre toda a terra. Porque, daqui a sete dias, farei chover sobre a terra durante quarenta dias e quarenta noites, e farei desaparecer da superfície do solo todos os seres que eu fiz." (GÊNESIS, 7, 1-5).

34 Cf. o artigo de Hans Janssen, Olaf Goubitz e Jaap Kottman, "Everyday objects in the paintings of Hieronymus Bosch", o pintor foi o único de seu tempo a retratar os dentes dos homens, o que os afastam de uma "crueldade satânica", humanizando-os. In. Hieronymus Bosch. New insights into his life and work, 2001, p. 191. 
sessions: no horror não se vê, no horror se escuta. No teatro artaudiano, a descrição do dramaturgo a respeito da peça de Ford exemplifica esse deslocamento (OC, 1978, p. 28) 35 $^{35}$

Sabendo-se que Nau dos insensatos, de Bosch possivelmente encontrou inspiração na obra homônima de Sebastian Brant, o momento epifânico da freira, que excede as demarcações de um dentro/fora, desafiando as limitações bíblicas anunciadas no livro Levítico, leva à experiência destoante da recomendação da cartilha de Brant, na qual defende o sigilo da vida interior: "Insensato é aquele que revela a sua mulher e a outros o que guarda em seu íntimo [...]” (2010, p. 147). Perdendo-se da intenção moralizante, o olhar da freira toca algum êxtase que desafia o que pode ser sentido no manual de literatura de massa da época medieval ${ }^{36}$.

O desafiar de Bosch que nos interessa, na medida em que conduz ao deslocamento da economia marcadamente visual, encontra na tela boschiana intitulada Bodas de Canã̃ importante índice para a consolidação da efemeridade característica da presença invisível. Havia, segundo Marcelle Gauffreteau-Sévy (1967, p. 34-35), que condensa uma série de pesquisas importantes sobre o trabalho e a vida de Bosch, algo de espiritual no trabalho dele, pintor que capturou o clima popular de sua cidade, possivelmente em função da própria condição precária da Idade Média, envolvida em frequentes episódios de incêndios que devastavam áreas habitadas, assim como a autora observa no incêndio em 1463 em 's-'Hertogenbosch, que marcaria a cidade e a infância do futuro pintor. A acrescentar a esse dado, Gauffreteau-Sévy (1967, p. 42) recupera a possível entrada de Bosch na Confraria de Nossa Senhora, que sempre foi receptiva a seguidores laicos. Já na época de Bosch, de acordo com a pesquisa de documentos e coleta de estudos a arquivos, nos anos de 1485-1486, a confraria passou de 319 para somente 35 religiosos. Havia suporte financeiro que vinha da nobreza dos países baixos e dos príncipes reais. Outra influência religiosa da época foi a confraria da Vida Comum, cujo fundador, Ruysbroeck ${ }^{37}$ (12931381) viveu, desde o ano de 1343, recluso no bosque de Soignes, além de ter colaborado no combate abusivo característico da prática de venda de indulgências. Estabeleceu-se uma estreita relação entre as confrarias, segundo a autora. Bosch foi influenciado pela obra de Ruysbroeck e ao mesmo tempo participou do ritual do cisne ${ }^{38}$, que era servido em banquetes da confraria da Nossa Senhora. Na investigação de Gauffreteau-Sévy, o pintor teria sido convidado a participar do banquete em homenagem à Virgem, ocasião em que

35 "Annabella é presa, condenada por adultério, incesto, humilhada, insultada, arrastada pelos cabelos, e é grande nosso estupor ao ver que, longe de procurar uma escapatória, ela provoca ainda mais seu carrasco e canta numa espécie de heroísmo obstinado" (ARTAUD, 2006, p. 25).

36 "É preciso lembrar que por aqui não existe nenhuma vida interminável e que todos nós seremos enviados deste mundo para um outro, desconhecido. Muitos já foram à frente, a morte nos chama, e um dia estaremos diante de Deus, seja para júbilo, seja para o tormento. Por isso, digas tu, tola ovelha, se há maior néscio sobre a terra do que aquele que junto contigo anseia por tais coisas [...] um instante é o que duram os prazeres aqui, e lá haverá eterna alegria - ou castigo." (BRANT, 2010, p. 127).

37 Artaud também entrou em contato com os textos de Ruysbroeck. Segundo Florence de Mèredieu, o autor da referência ao místico está numa carta de 1943, a Jean-Louis Barrault, cujo assunto trata de um poema que ele gostaria de fazer sob o título "La poésie et le chrétien", que seria um comentário de um poema de Mallarmé dedicado a Allan Poe. Conforme Mèredieu recupera da carta de Artaud, disponível em OC X (p. 102), há no poeta o contato com "os grandes místicos cristãos" e na lista de Artaud estão "Tauler, Ruysbroeck, Denys l'Aréopagite, Cassien, Ermengarde, Hildegarde et Sainte Brigitte" (1993, p. 77).

38 Cf. o artigo de Ester Vink, "Hieronyms Bosch's life in 's-Hertogenbosch", os cisnes eram servidos na qualidade de "prato principal" das comemorações em homenagem à Virgem Maria (2001, p. 21). 
serviam, anualmente, um cisne em bandeja de prata para os associados da confraria da Nossa senhora. Para Gauffreteau-Sévy (1967, p. 44), por trás da retratação do cisne em telas de Bosch, entre elas Bodas de Canaã e A tentação de Lisboa, sobressai um tom de "agressividade", correlato à simbologia pagã deste animal, que também pode ser interpretado junto à retratação de um hábito resumido em provérbio daquela cidade, no qual se observa o jogo de contrastes entre o claro e escuro constituinte de um sentido de tom moralizante que dizia o seguinte: "O cisne tem plumas brancas, mas a sua carne é negra" (1967, p. 34).

Interessa-nos não o possível apelo moralizador subjacente a esse contraste que não é apenas a complexidade do choque sofisticado de união com desvio ou apenas associação de contrários como outrora destacamos por intermédio do texto de Leiris ${ }^{39}$. Antes, a nossa intenção é a de trazer à superfície a volatilidade da retratação do fogo que acompanha o teatro da crueldade artaudiano, especialmente na imagem de invisível presença do cisne que cospe fogo, de As bodas de Canaã. Em "O teatro e a peste", a manifestação do fogo enaltecida por Artaud nos reenvia a telas de Van Gogh, ao se relacionar à imagem de um "estranho sol", que já não causa impacto porque se trata de "uma luz de intensidade anormal em que o difícil e mesmo o impossível tornam-se de repente nosso elemento normal $^{40}$ " (2006, p. 27). A tela de Bosch mostra-se também distanciada do abalo causado pelo impressionante quadro de Lucas van den Leyden, em "A encenação e a metafísica", no tocante à descrição do fogo, que, segundo Artaud, desperta "alguma coisa de terrivelmente enérgico e perturbador, como um elemento ainda em ação e móvel numa expressão imobilizada $^{41}$ " (2006, p. 33). A capturar o efeito da invisibilidade da presença, nesse momento de descrição das Filhas de Loth se passa de um horror da escuta para a tentativa de apreensão tátil de um incêndio que está, na escrita do autor, na ordem do "dilaceramento sonoro"42 (OC IV, 1978, p. 33-34).

A descrição dos instrumentos musicais do teatro da crueldade oferece outro exemplo de dilaceramento sonoro ${ }^{43}$ (OC IV, 1978, p. 92).

39 De acordo com Walter Bosing, desenha-se uma complexa ambiguidade nesta tela, pois o crítico admite a leitura de uma "alegoria moral da ambição humana pela satisfação carnal sacrificando o bem-estar eterno e, por outro lado, o ideal monástico de uma vida apartada da vida mundana virada para a contemplação de Deus" (2006, p. 22).

40 "Une lumière d'une intensité anormale où il semble que le difficile et l'impossible même deviennent tout à coup notre élément normal” (ARTAUD, OC IV, 1978, 30).

41 "quelque chose d'affreusement énergique, et de troublant comme un élément encore en action et móbile dans une expression immobilisée (ARTAUD, OC IV, 1978, 34).

42 "De repente, no crepitar de fogos de artifício, através do bombardeio noturno das estrelas, dos raios, das bombas solares, vemos de repente revelar-se a nossos olhos, numa luz de alucinação, em relevo sobre a noite, alguns detalhes da paisagem: árvores, torre, montanhas, casas, cuja iluminação e cuja aparição permanecerão para sempre ligadas em nosso espírito à ideia desse dilaceramento sonoro; não é possível exprimir melhor esta submissão dos diversos aspectos da paisagem ao fogo manifestado no céu do que dizendo que, embora tenham luz própria, permanecem relacionados ao fogo como espécies de ecos amortecidos, como pontos de referência vivos, nascidos do fogo e ali colocados para permitir que ele exerça toda a sua força de destruição" (ARTAUD, 2006, p. 33).

43 "Serão usados em sua condição de objetos e como se fizessem parte do cenário.

Além disso, a necessidade de agir diretamente e profundamente sobre a sensibilidade pelos órgãos convida, do ponto de vista sonoro, a que se procurem qualidades e vibrações de sons absolutamente incomuns, qualidades que os instrumentos musicais atuais não possuem, e que levam ao uso de instrumentos antigos e esquecidos, ou a criar novos instrumentos" (ARTAUD, 2006, p. 109). 


\section{Gestualidade pintada em jardins obscenos}

Artaud reconhece uma carga de violência no fogo, uma maldade, que, segundo ele, "ninguém pode negar", e que, no entanto, serve para um equilíbrio, pois a chama de "contrapeso no espírito para a estabilidade material e densa do resto" (2006, p. 33). Possivelmente, mais invisível do que o fogo, embora a retratação seja mais evidente, são aquelas plantas e flores dos Jardins das delícias, de Bosch. Como escreve Kristeva em Histórias de amor, no artigo "Baudelaire, ou l'infini, du parfum et du punk", a metáfora do perfume, desencadeada pelas Flores do mal baudelairianas, ou amplamente, na formação de qualquer sujeito falante, conduz à tentativa de apreensão de uma experiência arcaica por parte do poeta, uma vez que o perfume, na leitura de Kristeva, é anterior ao olhar (1983, p. 414). A invisível presença artaudiana encontra na metáfora do perfume a captura de uma invisibilidade presente no universo da linguagem poética que se encontra sutilmente em tela boschiana, sendo, portanto, sujeita a interpretações pictóricas. Na tela "A extração da pedra da loucura", cujo efeito do conjunto não é de sutilezas, há, no entanto, um elemento inesperado que se localiza no conteúdo da pseudo-operação, qual seja, a expectativa frustrada do objeto extraído que não é uma pedra: uma flor emana da cena.

No Jardim das delícias, o perfume se propaga de modo a disseminar o seu significado disfórico, na nossa recepção contemporânea. Paul Vandenbroeck ${ }^{44}$ reproduz a descrição incipiente do viajante italiano Antonio de Beatis, de 1527, secretário do cardeal Louis d'Aragon ${ }^{45}$.

Semelhante ao trabalho desenvolvido por Michel de Certeau ${ }^{46}$, cujo argumento central é que a tela de Bosch produz a perda do sentido e ao mesmo tempo nos leva a procurar por um possível sentido escondido nessa estética de arquitetura labiríntica, Lynn F. Jacobs ${ }^{47}$ acredita na possibilidade de uma interpretação ainda a ser escrita para o tríptico. Segundo Jacobs (2001, p. 65), o tríptico do Jardim das delícias rompe com a importância até então concedida ao painel central, na medida em que confere maior destaque ao exterior, através da imagem do cosmos no terceiro dia da criação; além disso, a composição boschiana permite uma maior unidade entre o interior e o exterior do que o tríptico tradicional. $\mathrm{O}$ aspecto mais interessante apontado por Jacobs (2001, p. 66) está no tamanho da tela, pois, apesar de haver no século 15 discretas retratações de um imaginário erótico em altares de igrejas, o quadro de Bosch excedia o costume das proporções, e, quando aberto, ampliava essas imagens consideradas pecaminosas, medindo 220x389 cm. Esse lado teatral da pintura de Bosch ecoa em dois momentos especiais do teatro da crueldade. O primeiro deles estaria no que Artaud chama de imprevisto, ao mencionar a cena, de um filme dos irmãos

44 No artigo "High Stakes in Brusels, 1517. The Garden of Earthly Delights as the crux of the conflit between William the silent and the Duke of Alva", em Hieronymus Bosch. New insights into his life and work. Vandenbroeck recupera os estudos de J.K. Steppe, que investigou a recepção da tela no século 16 .

45 Então existem mais alguns paineis com diversas excentricidades. Eles representam águas, o céu, florestas, campos, e muitas outras coisas, como pessoas rastejando dentro e fora de uma concha, outras que carregam pássaros, mulheres, povo e homens, brancos e negros fazendo todo tipo de coisas em todos os tipos de estados. Pode-se ver também pássaros e animais de todos os tipos, retratados muito naturalmente; coisas que são tão convincentes e fantásticas que é impossível descrevê-las para aqueles que não as viram por si mesmos (DE BEATIS apud VANDENBROECK, 2001, p. 87).

46 Cf. o capítulo "The garden: Delirium and delights". In. Mystic fable. The sixteenth and seventeenth centuries. Chicago: Chicago Press, 1993, p. 49-72.

47 Cf. "The Triptych unhinged: Bosch's garden of earthly delights”, 2001, p. 65. 
Marx, na qual um homem abraça uma vaca enquanto imagina abraçar uma mulher: "o que me parece melhor realizar em cena essa ideia de perigo é o imprevisto objetivo, o imprevisto não nas situações, mas nas coisas, a passagem intempestiva, brusca, de uma imagem pensada para uma imagem verdadeira ${ }^{48} "(2006$, p. 43). Outro aspecto a ser comparado com o exagero da tela boschiana reside na arquitetura imprevisível e de contato entre ator e espectador do teatro da crueldade (OC IV, 1978, p. 92-93).

No tocante à invisível presença, o aroma das flores e das plantas, que desenha o nosso argumento como sendo o gesto pintado mais sofisticado de efemeridade capturado por Bosch, desemboca no jogo de sexualidade em que homens e mulheres parecem desfrutar de um prazer sem culpa. Jean Delumeau, em Une histoire du paradis $T 1$, recupera algumas características que modelaram a imagem de felicidade em conexão com a sensação de tranquilidade, as quais são associadas, na história da literatura, aos jardins. Entre elas estão a "generosidade da natureza" e sua ligação com a água, com "eflúvios perfumados", a "ausência de sofrimento" e a "paz entre homens e animais" (1992, p. 15). Essa composição eufórica deve-se, segundo Delumeau (1992, p. 15-16), a obras tais como Os trabalhos e os dias, de Hesíodo; Eneida, de Virgílio; A metamorfose, de Ovídio e também ao IV canto da Odisseia, de Ulisses.

Contrastando com essa atmosfera aparentemente harmônica retratada por Bosch, Delumeau observa, na parte central do tríptico, a intrusão de elementos que nos conduzem não mais a um espaço de encantamento ou de tranquilidade, mas a um falso paraíso tocado pelo que chama de obscenidade: "através de um tubo de vidro, um rosto estranho observa um rato sob a esfera de cristal onde dois amantes se acariciam. À esquerda, a coruja gigante é o pássaro do Satã" (1992, p. 181). Para enfatizar essa representação disfórica dos jardins boschianos, há de se retornar à representação dos sapos nesse paraíso em decadência. Segundo Renilde Vervoort ${ }^{49}$ (2001, p. 150), os sapos acompanham a herança do Levítico, do Apocalipse e a Historia Naturalis de Plínio, que, em linhas gerais, os consideravam impuros e venenosos. Na aba direita do Jardim das delícias, por exemplo, há um sapo que repousa sobre o busto de uma mulher, que é descrita por Vervoort, apesar da comicidade da cena, como "orgulhosa" (2001, p. 150), uma vez que tem o rosto refletido em espelho localizado no traseiro de uma figura aparentemente demoníaca. As diferentes posições ocupadas pelos sapos em telas boschianas representam, de acordo com a análise de Vervoort (2001, p. 150), partes do corpo, tais como olhos, boca, seios e genitais, áreas erógenas que levam aos "prazeres da carne" e, portanto, constituem signos de proibição. O contato entre homens e mulheres em busca de prazer encontra no livro do Gênesis um exemplo de transgressão a tabu alimentar que retorna, nos jardins boschianos, através de uma série de frutos vermelhos, que distraem homens e mulheres desnudos, levando-os a esboços acrobáticos entre a leveza infantil e a interação com os elementos da natureza, de modo a promover uma espécie de colapso ou a sugerir o questionamento da herança bíblica ${ }^{50}$.

48 “Or ce qui me paraît devoir le mieux réaliser à la scène cette idée de danger est l'imprévu objectif, l'imprévu non dans les situations mais dans les choses, le passage intempestif, brusque, d'une image pensée à une image vraie" (ARTAUD, 1978, OC IV, p. 42).

49 Cf. o artigo "The pestilent toad. The significance of the toad in the works of Bosch". In. Hieronymus Bosch. New insights into his life and work, 2001, p. 145-152.

50 "Iaweh Deus plantou um jardim em Éden, no oriente, e aí colocou o homem que modelara. Iaweh Deus fez crescer do solo toda espécie de árvores famosas de ver e boas de comer, e a árvore da vida no meio do jardim, 
O deslocamento do primado visual acontece através de uma transgressão a um tabu que é alimentar, sendo este intimamente associado ao perfume do conjunto promovido pela cena, animada por uma gestualidade sobre a qual o período da Alta Idade Média contribuiu para alçar a um status de revolta. Na investigação de Jacques Le Goff, a escrita sobre a gestualidade configura uma linguagem que pode atuar como controle de uma sociedade, como foi o caso do período medieval. O historiador, ao elogiar e defender a recuperação da história da Idade Média, sob a perspectiva de J. Huizinga, no que diz respeito a buscas em torno da psicanálise e do que condensa sob o nome de "erotismo" (1989, p. 242), argumenta que este teria sido influenciado por um espaço de proximidade com os Países Baixos, passando, nessa medida, por tal "curiosidade", que teria sido desencadeada por telas de Bosch ${ }^{51}$. A gestualidade trabalhada por Bosch, em telas que congelam movimentos de uma época que guarda e desvela os perigos do corpo, constitui um documento visual e fantasmático de um domínio de cristandade $^{52}$, o que não significa, como defende Le Goff, recusar o retorno às diversidades de uma cultura.

As reflexões acerca do teatro de Artaud, portanto, promovem aproximações estéticas semelhantes àquelas produzidas pelas telas escolhidas de Bosch, que divide a cena pictórica ao lado de pintores como Lucas de Leyden, Goya, El Greco, Brueghel, O Velho (2006, p. 141). E no infortúnio de ausência de uma linguagem gestual no teatro, que, para Artaud, atua como uma linguagem que "iguala e supera a das palavras", esses pintores, em trabalhos citados por ele, cuja investigação, supomos, pode levar a fecundos estudos entre as artes dramáticas, a escrita sobre o universo pictórico e seus fantasmas originários, seriam substitutos daquilo que, na nossa síntese, em sintonia com fantasmas de superfície e possivelmente no cruzamento de fantasmas arcaicos, a serem também retomados em literatura e em diversas manifestações artísticas, no cruzamento efêmero com o íntimo, responde pelo nome de encantamento, encontrando-se desenvolvido na proposta artaudiana de metafísica da linguagem: “(...) c’est enfin considérer le langage sous la forme de l'Incantation"”53 (OC IV, 1978, p.45).

\section{Referências}

AIKEMA, B. Hieronymus Bosch: New Insights into His Life \& Work. [s.1.]: NAi Publishers/Museum Boijmans Van Beuningen, 2001.

ARISTÓTELES. Metafísica. Ed. bilíngue. São Paulo: Loyola, 2002. Trad. Giovanni Reale e Marcelo Perine.

e a árvore do conhecimento do bem e do mal. [...] Iaweh Deus tomou o homem e o colocou no jardim do Éden para o cultivar e o guardar. E Iaweh Deus deu ao homem este mandamento: 'Podes comer de todas as árvores do jardim. Mas a árvore do conhecimento do bem e do mal não comerás, porque no dia em que dela comeres terás que morrer"'" (GÊNESIS, 2, 8-18).

51 “(que é também a do outro grande historiador desta geração, Henri Pirenne, que vive entre paisagens e imagens com as de Bosch e de Bruegel), que é terra tradicionalmente aberta a este tipo de curiosidade" (LE GOFF, 1989, p. 242).

52 O gesto - meio expressivo privilegiado do paganismo e de Satanás, sempre pronto a desequilibrar-se para o lado do mal, demasiado ligado ao corpo, "o horrendo revestimento da alma, - apresentou-se, tal como o sonho, perigoso e suspeito aos olhos da Igreja dos primeiros séculos da Idade Média. O próprio termo gestus, tão comum nos textos antigos, e por maioria de razão o de gesticulatio, tornam-se raros nos textos da alta Idade Média" (LE GOFF, 1989, p. 71).

53 “(...) é enfim, considerar a linguagem sob a forma do Encantamento” (ARTAUD, 2006, p. 46-47). 
ARTAUD, A. Linguagem e vida, Antonin Artaud. São Paulo: Perspectiva, 2004.Trad. J. Guinsburg.

. Oeuvres complètes. Paris: Gallimard, 1978. t.4

. Nouveaux écrits de Rodez. Paris: Gallimard, 1977.

. O teatro e seu duplo. 3. ed. São Paulo: Martins Fontes, 2006. Trad. Teixeira Coelho.

Ouvres complètes. Paris: Gallimard, 1974. t.13

Ouvres complètes. Paris: Gallimard, 1976. t.1 v.2

Ouvres complètes. Paris: Gallimard, 1978. t.14

Ouvres complètes. Paris: Gallimard, 1980. t.2

Ouvres complètes. Paris: Gallimard, 1984. t.1 v.1

BÍBLIA de Jerusalém. 2. ed. São Paulo: Paulus, 2003.

BORIE, M. Pays de peinture et musique des sources. In: Le théâtre et le retour aux sources. Paris: Gallimard, 1989.

BOSING, W. A obra de pintura. Rio de Janeiro: Paisagem, 2006.

BRANT, S. A nau dos insensatos. São Paulo: Ed. Octavo, 2010. Trad. Karin Volobuef.

CERTEAU, M de. The garden: Delirium and delights. In: Mystic fable.

The sixteenth and seventeenth centuries. Chicago: Chicago Press, 1993.

DELUMEAU, J. Une histoire du paradis: le jardin des délices. Paris: Hachette

Littérature, 2002. v.1

DERRIDA, J. A palavra soprada. In:__. A escritura e a diferença. 3. ed. São Paulo:

Perspectiva, 2002. Trad. Maria Beatriz Marques Nizza da Silva.

. Artaud Moma: interjections d'appel. Paris: Galilée, 2002.

L'écriture et la différence. Paris: Ed. du Seuil, 1967.

GANGELEN, H.; OSTKAMP, S. Parallels between Hieronymus Bosch's imagery and decorated material culture from the period between circa 1450 and 1525. In: AIKEMA, B. Hieronymus Bosch. New insights into his life and work. [s.1.]: NAi Publishers/

Museum Boijmans Van Beuningen, 2001.

GAUFFRETEAU-SÉVY, M. Hieronymus Bosch: El Bosco. Barcelona: Editorial Labor, 1967.

GROSSMAN, É. Antonin Artaud. Un insurgé du corps. Paris: Gallimard, 2006.

JACOBS, L. F. The Triptych unhinged: Bosch's garden of earthly delights. In: AIKEMA,

B. Hieronymus Bosch. New insights into his life and work. [s.l.]: NAi Publishers/Museum Boijmans Van Beuningen, 2001.

JANSSEN, H; GOUBITZ, O; KOTTMAN, J. Everyday objects in the paintings of

Hieronymus Bosch. In: AIKEMA, B. Hieronymus Bosch. New insights into his life and work. [s.1.]: NAi Publishers/Museum Boijmans Van Beuningen, 2001.

KRISTEVA, J. Histoires d'Amour. Paris: Seuil, 1983.

. La révolte intime: pouvoirs et limites da psychanalyse II. Paris: Fayard, 1997.

La révolution du langage poétique. L'avant-garde à la fin du XIXe siècle.

Lautréamont et Mallarmé. Paris: Seuil, 1974.

. Possessions. Paris: Fayard, 1996.

. Sens et non-sens de la révolte: pouvoirs et limites de la psychanalyse I. Paris:

Fayard, 1996.

. Sentido e contra-senso da revolta: poderes de limites da psicanálise I. Rio de

Janeiro: Rocco, 2000. Trad. Ana Maria Scherer.

. Visions Capitales (avec Liudvig Feïerbakh). Paris: Réunion des musées nationaux, 1998. 
LE GOFF, J. O maravilhoso e o quotidiano no ocidente medieval. Lisboa: Edições 70, 1989. Trad. Antonio José Pinto Ribeiro.

LEIRIS, M. Espelho da tauromaquia. São Paulo: Ed. Cosac e Naify, 2001. Trad. Samuel Titan Jr.

MÈREDIEU, F de. C'était Antonin Artaud. Paris: Fayard, 2006.

NIETZSCHE, F. A gaia ciência. São Paulo: Companhia das Letras, 2007. Trad. Paulo César de Souza.

RUSSO, A. M. Art et oscillation: l'oeil d'un "certain philosophe”. In: HAREL, S. (Org.). Figures et portraits vertigineux. Montréal: XYZ, 1995.

THEVÉNIN, P. Dessin, peinture, theater. Antonin Artaud, ce désespéré qui vous parle. Paris: Seuil Fiction \& Cie, 1993.

. Un insurgé de l'art. Antonin Artaud, ce désespéré qui vous parle. Paris: Seuil

Fiction \& Cie, 1993.

VANDENBROECK, P. High Stakes in Brusels, 1517. The Garden of Earthly Delights as the crux of the conflit between William the silent and the Duke of Alva. In: AIKEMA, B. Hieronymus Bosch. New insights into his life and work. [s.1.]: NAi Publishers/ Museum Boijmans Van Beuningen, 2001.

VERVOORT, R. The pestilent toad. The significance of the toad in the works of Bosch. In: AIKEMA, B. Hieronymus Bosch. New insights into his life and work. [s.l.]: NAi Publishers/Museum Boijmans Van Beuningen, 2001.

VINK, E. Hieronyms Bosch's life in 's-Hertogenbosch. In: AIKEMA, B. Hieronymus Bosch. New insights into his life and work. NAi Publishers/Museum Boijmans Van Beuningen, 2001.

VIRMAUX, A. Artaud e o teatro. São Paulo: Ed. Perspectiva, 2000.

Recebido em: 22/06/2018 Aceito em: 26/08/2018 